\title{
Melanoma skin cancer: could chromone derivatives be efficient chemopreventors?
}

\author{
Mafalda M Dias ${ }^{1 *}$, Maria PM Marques ${ }^{1,2}$ \\ From 16th International Charles Heidelberger Symposium on Cancer Research \\ Coimbra, Portugal. 26-28 September 2010
}

Melanoma is a highly metastatic tumour and its incidence has ranked $5^{\text {th }}$ and $6^{\text {th }}$ among the most common cancer afflicting both men and women. Melanoma cells have a diminished antioxidant potential compared to normal melanocytes, which leads to an accumulation of ROS [1]. 1,4-benzopyrone heterocyclic compounds are widely distributed in plants and are reported to exhibit several biological roles, including antioxidant and free radical scavenging [2], displaying a variety of pharmacological properties such as anti-inflammatory and antitumour [3]. The present study aimed to assess the response of the melanotic human skin melanoma (A375) cell line to treatment with 8 different benzopyran derivatives (eg. fisetin, luteolin and quercetin) - in the concentration range $12.5-100 \mu \mathrm{M}$, for 24,48 and $72 \mathrm{~h}$ incubation periods (using the MTT assay). Reversibility of the drug effect (after 3 days) was also tested. Concomitantly, similar experiments were carried out for non-neoplasic, non-immortalised, human foreskin fibroblasts (BJ).

The results thus gathered allowed to conclude that the chromone derivatives are promising chemopreventive and/or chemotherapeutic agents towards melanoma, while having no considerable adverse effect against healthy cells.

\section{Author details}

${ }^{1}$ Research Unit "Molecular Physical Chemistry", University of Coimbra, Coimbra, Portugal. ${ }^{2}$ Department of Life Sciences, Faculty of Sciences and Technology, University of Coimbra, Coimbra, Portugal.

Published: 24 September 2010

\footnotetext{
* Correspondence: mafaldamdias@gmail.com

'Research Unit "Molecular Physical Chemistry", University of Coimbra, Coimbra, Portugal

Full list of author information is available at the end of the article
}

\section{References}

1. Yang Z, Yang S, Misner BJ, Chiu R, Liu F, Meyskens FL Jr: Nitric oxide initiates progression of human melanoma via a feedback loop mediated by apurinic/apyrimidinic endonuclease- $1 /$ redox factor- 1 , which is inhibited by resveratrol. Mol Cancer Ther 2008, 7:3751-3760.

2. Okawa M, Kinjo J, Nohara T, Ono M: DPPH (1,1-diphenyl-2-picrylhydrazyl) radical scavenging activity of flavonoids obtained from some medicinal plants. Biol Pharm Bull 2001, 24:1202-1205.

3. Pietta PG: Flavonoids as Antioxidants. J Nat Prod 2000, 63:1035-1042.

doi:10.1158/1535-7163.MCT-08-0562

Cite this article as: Dias and Marques: Melanoma skin cancer: could chromone derivatives be efficient chemopreventors?. BMC Proceedings 2010 4(Suppl 2):P28.
Submit your next manuscript to BioMed Central and take full advantage of:

- Convenient online submission

- Thorough peer review

- No space constraints or color figure charges

- Immediate publication on acceptance

- Inclusion in PubMed, CAS, Scopus and Google Scholar

- Research which is freely available for redistribution

Submit your manuscript at www biomedcentral.com/submit
C Biomed Central 